Lucrările Seminarului Geografic Dimitrie Cantemir

Vol. 45, October 2017, pp. 221-227

http://dx.doi.org/10.15551/lsgdc.v45i0.19

\title{
An agricultural soil between tillage and pasture
}

Daniela Răducu1 ${ }^{1}$ Rodica Lazăr ${ }^{1}$, Monica Dumitrașcu${ }^{1}$, Alexandrina Manea1 ${ }^{1}$ Alina Eftene ${ }^{1}$

${ }^{1}$ National Research and Development Institute for Soil Science, Agrochemistry and Environment, Bucharest, Romania

To cite this article: Răducu, D., Lazăr, R., Dumitrașcu, M., Manea, A. \& Eftene, A. (2017). An agricultural soil between tillage and pasture. Lucrările Seminarului Geografic Dimitrie Cantemir, Vol. 45, pp. 221-227. DOI: 10.15551/lsgdc.v45i0.19

To link to this article: http://dx.doi.org/10.15551/lsgdc.v45i0.19 


\title{
AN AGRICULTURAL SOIL BETWEEN TILLAGE AND PASTURE
}

\author{
Daniela Răducu ${ }^{1}$, Rodica Lazăr ${ }^{1}$, Monica Dumitrașcu ${ }^{1}$, \\ Alexandrina Manea ${ }^{1}$, Alina Eftene ${ }^{1}$
}

\begin{abstract}
Le but de cette publication est de souligner l'évolution au niveau morfomicromorphologique d'un sol influencé par le changement répète de l'utilisation du terrain (pâturage arable - pâturage). Le site étudié est situé dans la Dépression d'Oltenia, dans la région de Botorogi où le climat est continental tempéré, la température annuelle moyenne est de $10,2^{\circ} \mathrm{C}$, tandis que la précipitation annuelle moyenne est de $914,7 \mathrm{~mm}$. Le drainage naturel global est imparfait. La nappe phréatique a une profondeur de 2,5 à $3 \mathrm{~m}$. Le sol est Eutricambosol gleic aluvic (drainé) (selon SRTS2012 et Fluvic Endogleic Cambisol Eutric - selon WRB-SR-2014) formé dans des dépôts alluviaux avec texture limon argileux. Le profil du sol est situé sur un terrain qui a changé son utilisation plusieurs fois: du pâturage (de nombreuses années) en arable (quatre ans) et de terre arable on changé à nouveau dans le pâturage (actuellement). Les données corroborées (morphologiques, analytiques, micromorphologiques) conduisent à la conclusion que la compaction de l'horizon $\mathrm{Ao}_{2}(\mathrm{t})$ est causé par le passage fréquent de la charrue à la même profondeur, étant similaire à la ,semelle de labour ${ }^{\text {ce }}$. Après le changement répété de l'utilisation du terrain, la principale caractéristique d'un sol agricole (l'horizon labouré compactée Apt) restent résiduel dans le sol de pâturage, représenté par l'horizon $\mathrm{Ao}_{2}(\mathrm{t})$. Après quelques années de pâturage et dans les conditions d'une activité biologique relativement élevée, l'état structural du sol n'a pas été reconstruit, nécessitant plusieurs années pour le restaurer. Le suffixe „, $(\mathrm{t})^{\text {ee }}$ qui dérive de „,couche de compaction causé par le labour" a été proposé pour marquer la présence d'une ,semelle de labour"e résiduel, dans le sol actuellement sous pâturage
\end{abstract}

Keywords: agricultural soils, pasture, micromorphology, tillage

\section{Introduction}

Land use and vegetation respectively, lead the genesis of the pedogenetic horizons, so that soils developed in the ecosystems with different land use have specific pedogenetic horizons.

Răducu (2015) showed that soils from different ecosystems are characterized by one or more specific horizons which distinguish them from all other soils. As for example: the soils under the forest (irrespective of their type or subtype) have an organic $\mathrm{O}$ horizon, as well as the soils beneath the meadows or pastures have an Aţ horizon. In this respect, the soils from the arable land have in the upper part a layer affected by tillage, consisting of two horizons: Ap (ploughed) and Apt (ploughed compacted).

Into the Apt horizon of tilled plots it can be also noticed a strong reduction of regular and irregular pores, with respect to the upper Ap horizon; since these pores were mainly

\footnotetext{
${ }^{1}$ National Research and Development Institute for Soil Science, Agrochemistry and Environment ICPA Bucharest, 61 Mărăşti, 011464, sector 1, Bucureşti, Romania, daniela.icpa@yahoo.com.
} 
originated in the burrows of soil fauna, their decrease could be ascribed to a collapse due to compaction (Răducu et al., 2002).

Enhanced dynamics between soil biota, especially earthworms, carbon inputs and soil aggregation contributed to higher direct surface water infiltration when compared to conventional practices; whereas tillage prevented earthworm proliferation and topsoil organic carbon accumulation (Castellanos-Navarrete et al., 2012).

Larger organisms in general appear to be more sensitive to tillage operations than smaller organisms, due to the physical disruption of the soil, burial of crop residue, and the change in soil water and temperature resulting from residue incorporation (Kladivko, 2001).

Land use change and intensification in agricultural landscapes have resulted in widespread soil degradation and a loss in soil-based ecosystem services and biodiversity; this trend threatens the sustainability of farming communities with important implications for food security and biodiversity conservation (Valenca et al., 2017).

Soil degradation, characterized by decline in quality and decrease in ecosystem goods and services, is a major constraint to achieving the required increase in agricultural production (Lal, 2015).

Land use change derived by human activities is considered the most important factor for biodiversity losses, and a large number of studies have documented the negative effects of land use change for plants, animals and most recently microorganisms (Navarrete et al., 2016).

The aim of the paper is to emphasize the evolution at morpho-micromorphological level of a soil influenced by the repeated changing of the land use (pasture - arable pasture).

\section{Material and methods}

The investigated site is located in Oltenia Depression, in the Botorogi region where the climate is temperate continental, and the bioclimate is deciduous forest (oak forests). The average annual temperature is of $10.2^{\circ} \mathrm{C}$, while the average annual rainfall is $914.7 \mathrm{~mm}$. The global natural drainage is imperfect. The water table is at $2.5-3 \mathrm{~m}$ depth. The soil is Eutricambosol gleic aluvic (drained) (according to SRTS-2012; and Fluvic Endogleic Cambisol Eutric - according to WRB-SR-2014) formed in fluvic clayey-loam deposits.

The soil was sampled (disturbed for physical and chemical analysis; and undisturbed for the micromorphological study) and analyzed according to the standard methods of ICPABucharest (ICPA Methodology-1987). The micromorphological undisturbed samples were air drayed and impregnated with epoxidic resins. After hardening, oriented thin sections (25 - 30 $\mu \mathrm{m})$ have been made from each sample and studied with Documator $(20 \mathrm{X})$ and optical microscope (50-100 X) in PPL (plain polarized light) and XPL (cross polarized light). The terminology used for micromorphological description was according to Bullock et al. (1985).

\section{Results and discussions}

The studied site is located on a land that repeated change the land use: from pasture (many years) to arable (four years), and from arable back to pasture (at present).

The morphological characteristics of the studied soil revealed, during the expeditionary field observations, important characteristics of the structure and poral system (comparing to a classic soil formed under pasture). 
At the soil surface an Aț $(0-8 \mathrm{~cm})$ horizon consisting of root felt (re-)appear during the last years of pasture land use. The terrous material between the roots was clayey. The structure determined in the field (at the soil water state: dry-moist) is fine and very fine granular. Common coprolites are present, among the vegetal remains. The lower boundary of the horizon is abrupt, smooth.

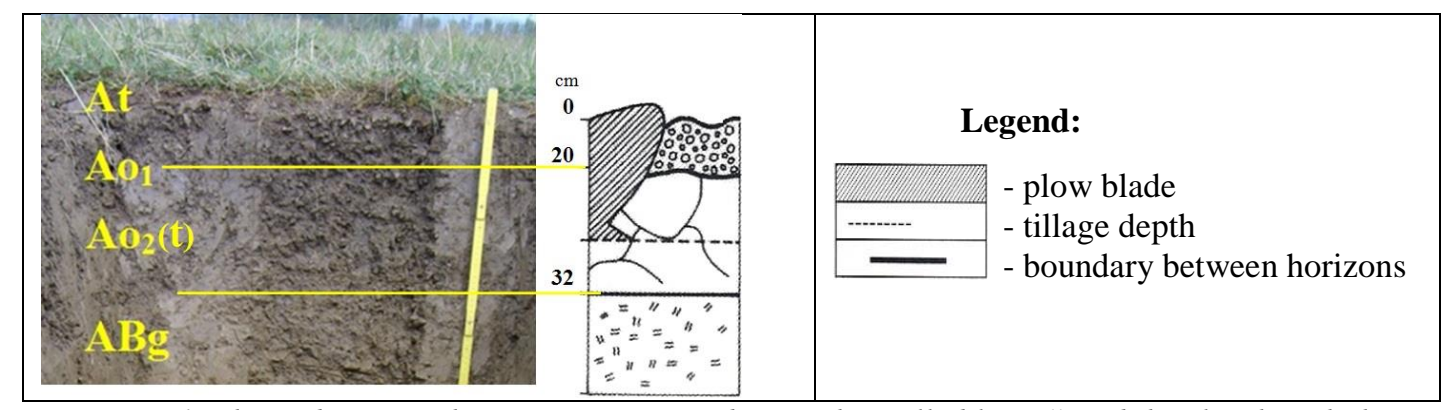

Figure 1. The pedogenetic horizons corresponding to the "tilled layer" and the sketch with the ploughed depth

The $\mathrm{Ao}_{1}(8-20 \mathrm{~cm})$ horizon (formed below the Aţ) had clayey texture and the structure (determined in the field at the soil water state: dry-moist) was medium - fine subangular blocky (still bearing the influence of tillage, prior to the meadow land use). The soil is moderately compact and extremely firm when moist, but very hard when dries. In what concerning the porosity, it consists of many fine pores. Medium earthworm channels (many of them with coprolites) also appear in the horizon. Fine roots were common, while the medium ones were few. The boundary to the next horizon was clear, smooth.

$\mathrm{The} \mathrm{Ao}_{2}(\mathrm{t})(20-32 \mathrm{~cm})$ horizon had clayey texture. The structure was medium - coarse angular blocky (determined at the soil water state: moist) and the horizon is very compact (strongly bearing the influence of tillage, prior to the meadow land use). The soil is extremely firm when moist, and very hard when dries. The porosity consists of common fine pores. Soil biological activity was highlighted by the presence of medium channels and common medium coprolites created by soil fauna. Fine roots were few. The lower boundary of the horizon was abrupt, smooth.

The $\mathrm{ABg}$ horizon $(32-50 \mathrm{~cm})$ was silty clay and had medium angular blocky structure (determined in the field at the soil water state: wet). The horizon is medium compact, and extremely firm when moist, but very hard when dries. Porosity consists of common fine pores. The biological activity was highlighted, as in the upper horizon, by the presence of common medium channels and coprolites (created by soil fauna). Fine roots were few. In this horizon redoximorphic features (as Fe \pm Mn oxihydroxides mottles) were observed.

The analytical data showed that soil granulometry was clayey in the upper part of the soil profile, the clayey fraction being dominant (Figure 2), with values ranging from $46.7 \%$ in the compacted horizon $\left(\mathrm{Ao}_{2}(\mathrm{t})\right)$ to $51.2-51.4 \%$ in the two surface horizons (Aț and $\mathrm{Ao}_{1}$ respectively). 


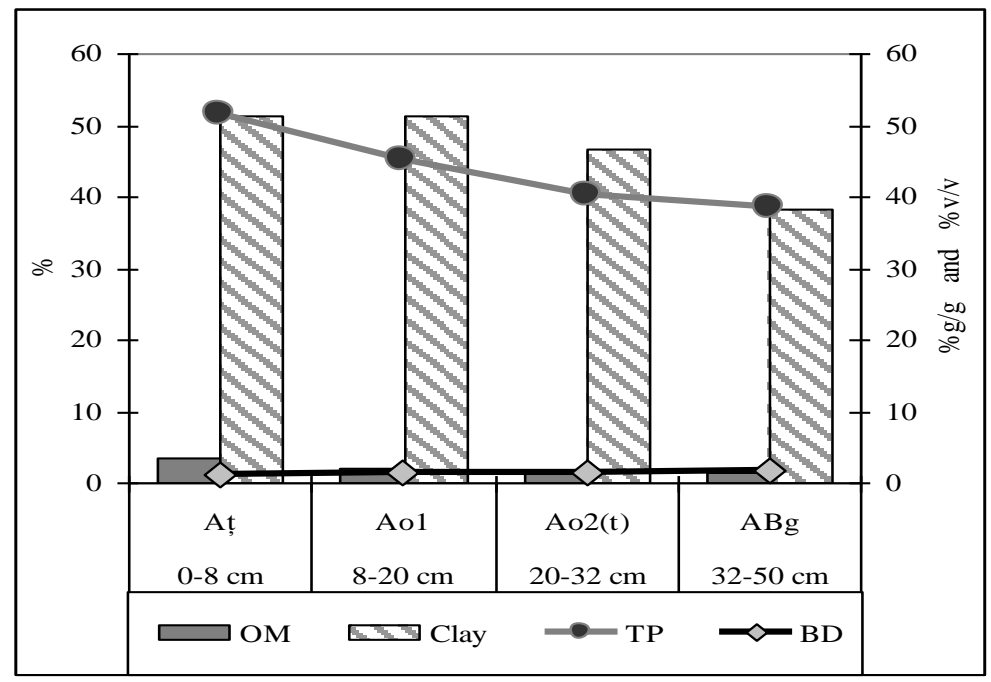

Figure 2. Physico-chemical characteristics of the studied soil

On the general background of this clayey profile, the bulk density (Figure 2) is medium $(1.28 \% \mathrm{~g} / \mathrm{g})$ in the top Aț, and big $(1.46 \% \mathrm{~g} / \mathrm{g})$ in the underlined $\mathrm{Ao}_{1}$ horizon. Into the compacted $\mathrm{Ao}_{2}(\mathrm{t})$ horizon, the value of the bulk density increased to very high $(1.58 \%$ $\mathrm{g} / \mathrm{g})$.

The total porosity (Figure 2) is very small - medium, the highest value being recorded in the surface horizon (due to common biological porosity created by the roots). This value decreased slightly (at $45.1 \% \mathrm{v} / \mathrm{v}$ ) in $\mathrm{Ao}_{1}$ horizon and drastically (at $40.4 \% \mathrm{v} / \mathrm{v}$ ) in the more compacted $\mathrm{Ao}_{2}(\mathrm{t})$. The values of the bulk density and the total porosity pointed out that the Aț horizon is slightly compacted, the $\mathrm{Ao}_{1}$ is moderately compacted, while the $\mathrm{Ao}_{2}(\mathrm{t})$ horizon is highly compacted.

Correlating all these analytical data with the soil organic matter content (Figure 2), it can be underlined that humus is relatively low (for a soil under pasture). This could be, probably, a consequence of the grubbing up the pasture for cultivation, as well as of the short time of post-agricultural reinstallation of pasture vegetation. Under these conditions, the organic matter content is low (3.36\%) in the A horizon and drastically decreases to 1.98 and 1.74 respectively in $\mathrm{Ao}_{1}$ and $\mathrm{Ao}_{2}(\mathrm{t})$ horizon respectively.

The micromorphological study (by the aim of the optical microscope) showed that the soil was formed in un-uniform parental material, according to the quality, quantity and the size of the skeleton grains that differ widely between the pedogenetic horizons. In $\mathrm{Ao}_{2}(\mathrm{t})$ horizon the skeleton grains becomes very abundant compared to the upper At and $\mathrm{Ao}_{1}$ horizons, and still remains to a high level up to $\mathrm{Bv}_{2} \mathrm{Go}(80-100 \mathrm{~cm})$ where the amount and the size of the skeleton grains strongly decreased.

The soil matrix is dominated by the clayey plasma component that formed stipplespeckled b-fabric, strongly birefringent, emphasizing clay orientation during fluviclacustrian deposition. Biological activity is very intense in the surface horizons (Aț and Ao), where the biological pedofeatures are very abundant, generated by the activity of phyto-, terro- and coprofagus soil fauna. 
It is worth mentioning that although under the pasture and with a relatively high biogenic activity, in the soil profile there is no bioturbation. This could be due to the moisture excess in the lower part of the soil profile $(50-165 \mathrm{~cm})$ that hinder the vertical movement of the soil fauna.

This moisture excess favored periodic waterlogging and anaerobic conditions, and generated redoximorphic features (slightly different in terms of extension and localization) starting with the horizon $\mathrm{ABg}$ (Figure 3) and ending with the $\mathrm{CnGr}$ horizon (120 -165 cm Figure 4), giving them a mottled appearance.

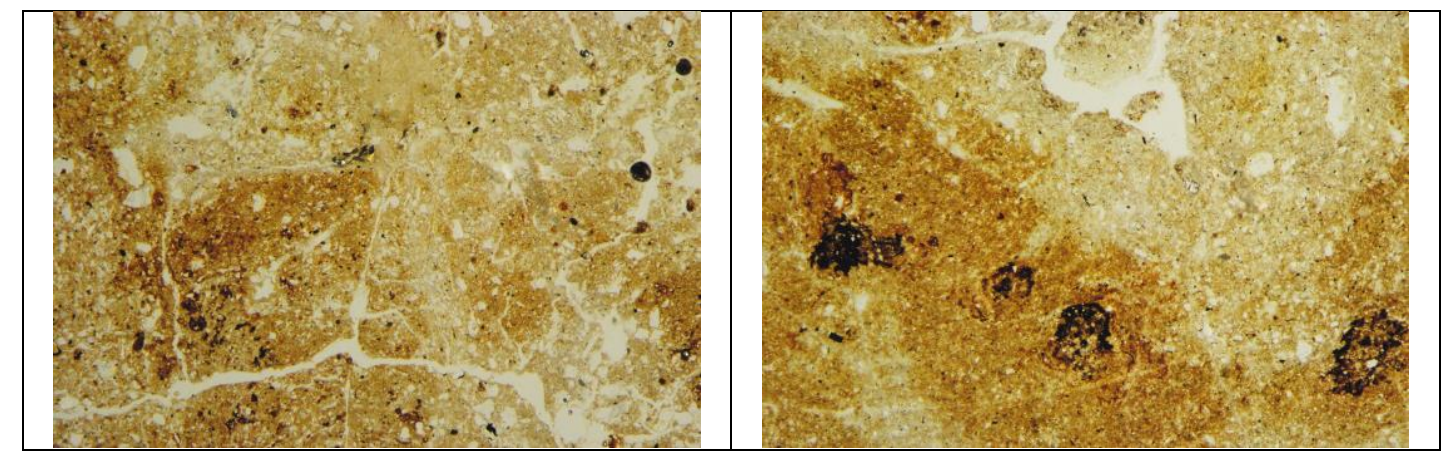

Figure 3. ABg $(32-50 \mathrm{~cm})$ horizon:

ferruginous \pm Mn mottles surrounded by zones depleted of $\mathrm{Fe} \pm \mathrm{Mn}$
Figure 4. Bv $v_{2}$ Go $(80-100 \mathrm{~cm})$ horizon: zones depleted of $\mathrm{Fe} \pm \mathrm{Mn}$ in the pore walls; ferruginous \pm Mn mottles inside the matrix

The amorphous pedofeatures (as ferruginous $\pm \mathrm{Mn}$ mottles) appear surrounded by the depletion pedofeatures (zones depleted of $\mathrm{Fe} \pm \mathrm{Mn}$ ) in $\mathrm{ABg}$ horizon (Figure 3). In the $\mathrm{CnGr}$ horizon, the amorphous pedofeatures are clearly located (Figure 4): the zones depleted of $\mathrm{Fe} \pm \mathrm{Mn}$ were formed in the pore walls, while the ferruginous $\pm \mathrm{Mn}$ mottles (also containing aggregate nodules) formed inside the soil matrix.

In what concerning the micromorphological features as reminiscence of tillage during the arable land use, in the $\mathrm{Ao}_{2}(\mathrm{t})$ horizon, the close porosity (represented by simple packing voids), as well as vughy structure (generated by the collapsed of the biogenic pedofeatures) were observed. In these conditions, the type and the evolution of the $\mathrm{Ao}_{2}(\mathrm{t})$ horizon should be understand throughout the tillage influence.

Thus, the shape and the size, as well as the 3-D arrangement of the structural elements and the adjacent pores, depends on the agricultural tools geometry and the ped kinetic during tillage. The spatial arrangement (loosed or stuffed) of the aggregates are closely dependent on their kinetic received from the agricultural tools during tillage. The main mechanism of soil compaction (in this horizon) is due to the plowing at the same depth and to the well pressure (both on soil surface and into the furrow) during the short time of the land use as arable.

Even if the soil was few years under pasture and consequently the compacted $\mathrm{Ao}_{2}(\mathrm{t})$ horizon under the influence of many restoring processes (fragmentation during wettingdrying as well as during freezing-thawing; structuring under biological activity etc.) the structural state of the soil was not improved, its restoration requiring a longer period of time.

In the conditions of a remnant tilled layer in the pasture soil, there is no possibility of marking it in the morphological description. In the soil classification (SRTS-2012): there is 
neither a ,prefix ${ }^{e e}$, nor a ,,suffix ${ }^{e e}$ for this remnant layer. Thus, in the paper it is proposed the suffix ,(t) from ,compacted under tillage (tasat - in Romanian), as it is used for the Apt horizon formed in the agricultural soils. The suffix was already used for the more compacted $\mathrm{Ao}_{2}$ horizon $\left(\mathrm{Ao}_{2}(\mathrm{t})\right)$.

\section{Conclusions}

The following conclusions can be drawn:

- The corroborated (morphological, analytical, micromorphological) data lead to the conclusion that the compaction of the $\mathrm{Ao}_{2}(\mathrm{t})$ horizon was due to tillage.

- After the repeated changing of the land use (pasture - arable - pasture) the main characteristics of an agricultural soil (the compacted Apt horizon) persist in the pasture soil as a remnant tilled feature $\left(\mathrm{Ao}_{2}(\mathrm{t})\right.$ horizon).

- After few years of pasture and under the conditions of a relatively high biological activity, the structural state of the soil was not reconstructed, requiring a longer period of time to restore.

- The suffix „(t) presence of a remnant tilled layer, in the soil under pasture.

\section{Acknowledgments}

The researchers were performed within the projects: PN 16070105 „Utilizarea tehnicii micromorfologice în studiul biodiversităţii din solurile agricole - suport pentru serviciile ecosistemice produse de sol” (,The utilization of micromorphological techniques in the study of the biodiversity from agricultural soils - support for the ecosystem services provide by soil").

\section{References}

1. Bullock P., Fedoroff N., Jongerius A., Stoops G., Tursina T., Babel U., 1985. Handbook for soil thin section description. Wine Research Publication: $152 \mathrm{pp}$.

2. Castellanos-Navarrete A., Rodriguez-Aragones C., Goede de R.G.M., Kooistra M.J., Sayre K.D., Brussaard L., Pulleman M.M., 2012. Earthworm activity and soil structural changes under conservation agriculture in central Mexico. Soil and Tillage Research, Vol. 123: 61-70.

3. Florea N., Munteanu I., 2012. Sistemul român de taxonomia solurilor (SRTS-2012). Editura Estrafia, Bucureşti, Romania: 206 pp.

4. Kladivko E.J., 2001. Tillage systems and soil ecology. Soil and Tillage Research, Vol. 61, Issues 1-2: 61-76.

5. Lal R., 2015. Restoring Soil Quality to Mitigate Soil Degradation. Sustainability, vol. 7: 58755895.

6. Navarrete A.A., Venturini A.M., Meyer K., Klein A.M., Tiedje J.M., Bohannan B.J.M., Nusslein K., Tsai S.M., Rodrigues J.L.M., 2016. Differential response of Acidobacteria subgroups to forest-topasture conversion and their biogeographic pattern in the western Brazilian Amazon. In: S. Pajares, B.J.M. Bohannan, V. Souza (Eds.) The Role of Microbial Communities in Tropical Ecosystems. Frontiers in Microbiology: 92-101.

7. Răducu D., 2015. Indreptar de Teren pentru Diagnosticarea, clasificarea și descrierea morfologică a solurilor. Editura Fundației România de Mâine, București: 211 pp.

8. Răducu D., Vignozi N., Pagliai M., Petcu Gh., 2002. Soil structure of tilled horizons influenced by management practices and implement geometry. CATENA VERLAG: 149-162. 
9. Valenca A.W., Vanek S.J., Meza K., Ccanto R., Olivera E., Scurrah M., Lantinga E.A., Fonte S.J., 2017. Land use as a driver of soil fertility and biodiversity across an agricultural landscape in the Central Peruvian Andes. Ecological application, Vol. 27, Issue 4: 1138-1154. 